\title{
Properties of a potassium channel in cultured human gastric cells (HGT-1) possessing specific omeprazole binding sites
}

\author{
G I Sandle, G Fraser, K Fogg, G Warhurst
}

\begin{abstract}
The HGT-1 human gastric cell line is similar to acid secreting parietal cells in that it possesses $\mathrm{H}_{2}$ receptors, histamine sensitive adenyl cyclase, and $\mathrm{Cl}^{-}$channels, which are activated by histamine by a cyclic adenosine monophosphate (cAMP) dependent mechanism. To discover if HGT-1 cells have additional properties found in parietal cells, $\left[{ }^{3} \mathrm{H}\right]$ omeprazole and patch clamp recording techniques were used to evaluate specific omeprazole binding sites and $\mathrm{K}^{+}$channels in the plasma membrane. HGT-1 cells exhibited $\left[{ }^{3} \mathbf{H}\right]$ omeprazole binding in the non-stimulated state, which increased $100 \%$ in the presence of $1 \mathrm{mM}$ histamine. High conductance (about 155 pS) $\mathrm{K}^{+}$channels were active spontaneously in $17 \%$ of cell attached or excised inside out patches in non-stimulated subconfluent HGT-1 cells. In inside out patches, channel activity increased fivefold during depolarisation, ion substitution experiments confirmed that the channels were highly selective for $\mathrm{K}^{+}$, and channel activity was almost abolished by removal of $\mathrm{Ca}^{2+}$ or addition of $5 \mathrm{mM} \mathrm{Ba}{ }^{2+}$. In quiescent cell attached patches, $0.1 \mathrm{mM}$ dibutyryl cAMP failed to activate $K^{+}$channels. In contrast, $6 \cdot 7$ $\mu M \quad A 23187$ (a $\mathrm{Ca}^{2+}$ ionophore) increased intracellular $\mathrm{Ca}^{2+}$ concentration from mean (SEM) 14 (3) $n M$ to 248 (30) nM and activated $\mathrm{K}^{+}$channels in $21 \%$ of patches. It is concluded that the plasma membrane of HGT-1 cells possesses (a) specific ${ }^{3} \mathrm{H}$-omeprazole binding sites, which may reflect the omeprazole sensitive $\mathrm{H}^{+}, \mathrm{K}^{+}$-ATPase present in gastric parietal cells; and (b) $\mathrm{Ca}^{2+}$-activated $\mathrm{K}^{+}$channels, which may be located in the basolateral membrane of human gastric parietal cells and play a part in acid secretion triggered by $\mathrm{Ca}^{2+}$. mediated secretory agonists.

(Gut 1993; 34: 1331-1338)
\end{abstract}

Hydrochloric acid secretion by gastric parietal cells entails complex ion transport events at the apical (secretory) membrane. Movement of $\mathrm{Cl}^{-}$ across the apical membrane of stimulated parietal cells seems to be mediated by $\mathrm{Cl}^{-}$ channels. ${ }^{12}$ In addition, apically located $\mathrm{H}^{+}, \mathrm{K}^{+}$, ATPase exchanges one $\mathrm{H}^{+}$ion for one $\mathrm{K}^{+}$ion, and is therefore dependent on the presence of luminal $\mathrm{K}^{+} .^{3-5}$ Although the precise mechanism by which $\mathrm{K}^{+}$moves from cell cytosol to the lumen of the gastric gland is unclear, a number of mechanisms that link apical $\mathrm{K}^{+}$and $\mathrm{Cl}^{-}$transport have been proposed namely - solely electroneutral $\mathrm{KCl}$ cotransport, ${ }^{6}$ electroneutral $\mathrm{KCl}$ cotransport in parallel with a large $\mathrm{Cl}^{-}$conduct- ance, ${ }^{7} \mathrm{~K}^{+}$movement by a population of $\mathrm{K}^{+}$specific channels in parallel with apical $\mathrm{Cl}^{-}$ channels, ${ }^{18}$ and simultaneous $\mathrm{K}^{+}$and $\mathrm{Cl}^{-}$movement mediated by an apical cotransporter with partial conductive properties.' Gastric parietal cells also possess a basolateral $\mathrm{K}^{+}$conductive pathway ${ }^{10}$ in parallel with $\mathrm{Na}^{+}, \mathrm{K}^{+}$-ATPase pump units, which mediate basolateral $\mathrm{K}^{+}$ uptake. This pump - leak system allows $\mathrm{K}^{+}$ions to recycle across the basolateral membrane, promotes hyperpolarisation of the parietal cell, and thereby contributes to the maintenance of the electrochemical gradient that favours $\mathrm{Cl}^{-}$ exit at the apical membrane during acid secretion.

A human gastric cell line (HGT-1) is now available, the properties of which have been partially characterised. Similar to gastric parietal cells, the plasma membrane of HGT-1 cells bears $\mathrm{H}_{2}$ receptors and intracellular cyclic adenosine monophosphate (cAMP) concentrations rise in response to histamine. ${ }^{11}$ The cells also possess outward rectifying, voltage sensitive, low conductance $\mathrm{Cl}^{-}$channels, which are activated by histamine by a cAMP dependent process, ${ }^{12}$ and may represent the apical $\mathrm{Cl}^{-}$channel activated in parietal cells during acid secretion. The aim of this study was to establish whether HGT-1 cells have additional features in common with gastric parietal cells. The results show that the plasma membrane of HGT-1 cells contains (a) specific binding sites for omeprazole that probably reflect omeprazole sensitive $\mathrm{H}^{+}, \mathrm{K}^{+}$-ATPase units; and (b) high conductance $\mathrm{K}^{+}$channels that may represent the $\mathrm{K}^{+}$channels present in the basolateral membrane of gastric parietal cells.

\section{Methods}

$\left[{ }^{3} \mathrm{H}\right]$ OMEPRAZOLE BINDING SITES

Monolayers of the HGT-1 human gastric cell line (and the HT29-19A human colonic cell line) were grown to confluency in 12-well plastic culture plates, and maintained in Dulbecco's modification of Eagle's minimum essential medium, supplemented with $2 \mathrm{mM} \mathrm{L}$-glutamine, $100 \mathrm{IU} / \mathrm{ml}$ penicillin, $100 \mu \mathrm{g} / \mathrm{ml}$ streptomycin, and $10 \%(\mathrm{vol} / \mathrm{vol})$ fetal calf serum (heat treated at $55^{\circ} \mathrm{C}$ for 30 minutes). Monolayers were grown in a humidified atmosphere of $95 \%$ air $/ 5 \% \mathrm{CO}_{2}$ at $37^{\circ} \mathrm{C}$. Culture medium was removed, and the cell layers washed with a buffered $\mathrm{NaCl}$ solution containing $(\mathrm{mM}): \mathrm{Na}^{+}, 140 ; \mathrm{K}^{+}, 4.5 ; \mathrm{Cl}^{-}, 149$; $\mathrm{Ca}^{2+}, 1 \cdot 2 ; \mathrm{Mg}^{2+}, 1 \cdot 2$; glucose 10 ; and $4-(2-$ hydroxyethyl,-1-piperazine ethanesulphonic acid(HEPES) 10 , titrated to $\mathrm{pH} 7 \cdot 4$ with $\mathrm{NaOH}$, 
and incubated with $\left[{ }^{3} \mathrm{H}\right]$ omeprazole $(1 \cdot 25 \mathrm{nmol} /$ well; equivalent to about $3 \times 10^{5}$ counts per min) in the presence or absence of $1 \mathrm{mM}$ histamine for 30 minutes at $37^{\circ} \mathrm{C}$. Histamine was used at a concentration of $1 \mathrm{mM}$ because previous studies have shown this concentration is required to achieve maximal stimulation of adenylate cyclase in the HGT-1 cell line,,$^{13}$ which is largely $(77 \%)$ inhibited by $10^{-4} \mathrm{M}$ cimetidine, an $\mathrm{H}_{2}$ receptor antagonist." Non-specific binding was assessed by incubating identical wells with $\left[{ }^{3} \mathrm{H}\right]$ omeprazole in the presence of $10 \mu \mathrm{M}$ unlabelled omeprazole. Incubation was stopped by rapid washing $(4 \times 2 \mathrm{ml}$ over $10 \mathrm{~s})$ with ice cold buffer. The cell layers were dissolved in $1 \%$ Triton $\mathrm{X}-100$, sonicated, and samples taken for scintillation counting and protein determination. ${ }^{14}$ Specific binding was calculated as the difference in cell associated counts between incubations with $\left[{ }^{3} \mathrm{H}\right]$ omeprazole alone, and $\left[{ }^{3} \mathrm{H}\right]$ omeprazole plus unlabelled omeprazole. Results are expressed as pmol omeprazole bound/mg cell protein.

\section{PATCH CLAMP STUDIES}

Monolayers of HGT-1 cells were maintained as described above, and cells were subcultured under identical conditions at 7 day intervals. Cells from passages 45-65 were grown on uncoated plastic coverslips and used 4-15 days after subculture. Subconfluent monolayers remained attached to coverslips, which were placed in a small chamber (vol $2 \mathrm{ml}$ ) and visualised on the stage of a Nikon (Diaphot) inverted microscope with Hoffmann modulated optics ( $\times 400$ magnification). The microscope was mounted on a vibration isolation table. Single channel recordings were obtained from membrane patches in cell attached and excised inside out configurations as described previously. ${ }^{15}$ In all experiments the bath solution (temperature $20-22^{\circ} \mathrm{C}$ ) initially contained $(\mathrm{mM})$ : $\mathrm{K}^{+}, 145 ; \mathrm{Cl}^{-}, 149: \mathrm{Ca}^{2+}, 1 \cdot 2 ; \mathrm{Mg}^{2+}, 1 \cdot 2$; glucose 10; and HEPES 10, titrated to $\mathrm{pH} 7 \cdot 4$ with $\mathrm{KOH}$ (high $\mathrm{K}^{+}$solution), and the pipette contained the $\mathrm{NaCl}$ solution (see above). In some experiments with inside out patches, single channel recordings were obtained after replacing the high $\mathrm{K}^{+}$solution with a low $\mathrm{K}^{+}$solution containing $(\mathrm{mM}): \mathrm{K}^{+}, 22 \cdot 5 ; \mathrm{Na}^{+}, 122 \cdot 5 ; \mathrm{Cl}^{-}$, $149 ; \mathrm{Ca}^{2+}, 1 \cdot 2 ; \mathrm{Mg}^{2+}, 1 \cdot 2$; glucose 10 ; and HEPES 10 , titrated to $\mathrm{pH} 7 \cdot 4$ with $\mathrm{NaOH}$. The Goldman-Hodgkin-Katz (GHK) current and voltage equations ${ }^{16}{ }^{17}$ were used to calculate the $\mathrm{K}^{+}: \mathrm{Na}^{+}$permeability ratios $\left(\mathrm{P}_{\mathrm{K}}: \mathrm{P}_{\mathrm{Na}}\right)$ and the reversal potentials $\left(\mathrm{E}_{\text {rev }}\right)$ respectively. Pipette resistances varied between 2-15 M $\Omega$ and membrane seal resistances between 5-40 G $\Omega$. The bath electrode was a silver chloride coated silver wire.

Single channel currents were recorded with a patch clamp amplifier (List Electronics, Darmstadt, Germany, model EPC-7), and stored on video tape after pulse code modulation (Sony, Japan, model PCM 701ES). Stored currents were low pass filtered $(-3 \mathrm{~dB}, 4$-pole Butterworth) at $1 \mathrm{kHz}$ and loaded into computer memory (IBM PC 286-XT, sampling frequency $4 \mathrm{kHz}$ ) through a Labmaster TL1 interface and TM40 A/D converter (Axon Instruments, Foster City, Ca, USA). Voltages applied to the membrane patches $\left(V_{\text {com }}\right)$ were referenced to the interior of the patch pipette. With high $\mathrm{K}^{+}$ solution in the bath, cell membrane voltage was assumed to be zero, and $\mathrm{V}_{\text {com }}$ was therefore equivalent to the potential across the membrane patch in both the cell attached and inside out configurations. Current-voltage $\left(\mathrm{I}-\mathrm{V}_{\text {com }}\right)$ rela-
A

$+60 \mathrm{mV}$

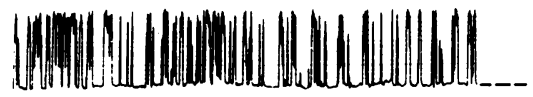

$+40 \mathrm{mV}$

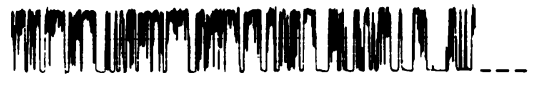

$+20 \mathrm{mV}$

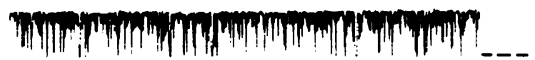

B

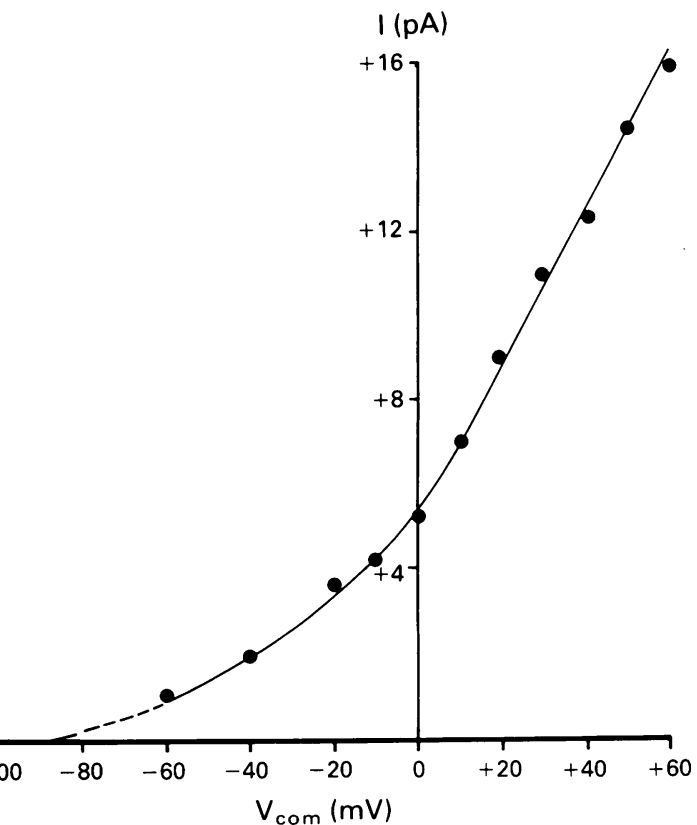

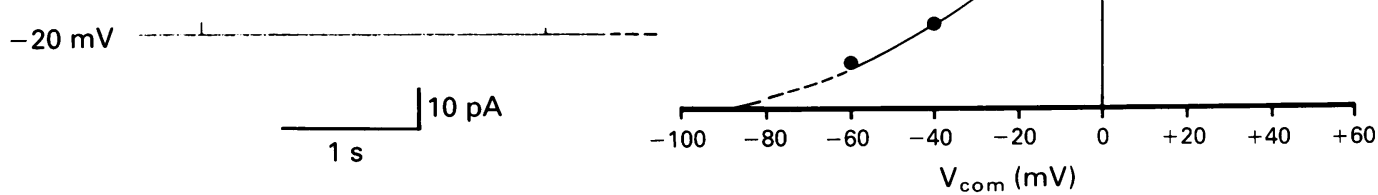

Figure 1: $K^{+}$channel in a cell attached patch of an HGT-1 cell (high $K^{+}$bath solution, NaCl pipette solution). (A) shows recordings at different holding potentials $\left(V_{\mathrm{com}}\right)$ referenced to pipette interior. Dashed lines show zero current values. Upward current deflections show outward $K^{+}$flow from cell to pipette. In this patch, channel openings were infrequent at $V_{\text {com }}$ values between $-20 \mathrm{mV}$ and $-60 \mathrm{mV} .(B)$ shows current/voltage $\left(I / V_{\text {com }}\right)$ relation of the recordings in $(A)$. Data fit and reversal potential $\left(E_{\text {rev }}\right)$ obtained using the Goldman-Hodgkin-Katz $(G H K)$ current and voltage equations. 

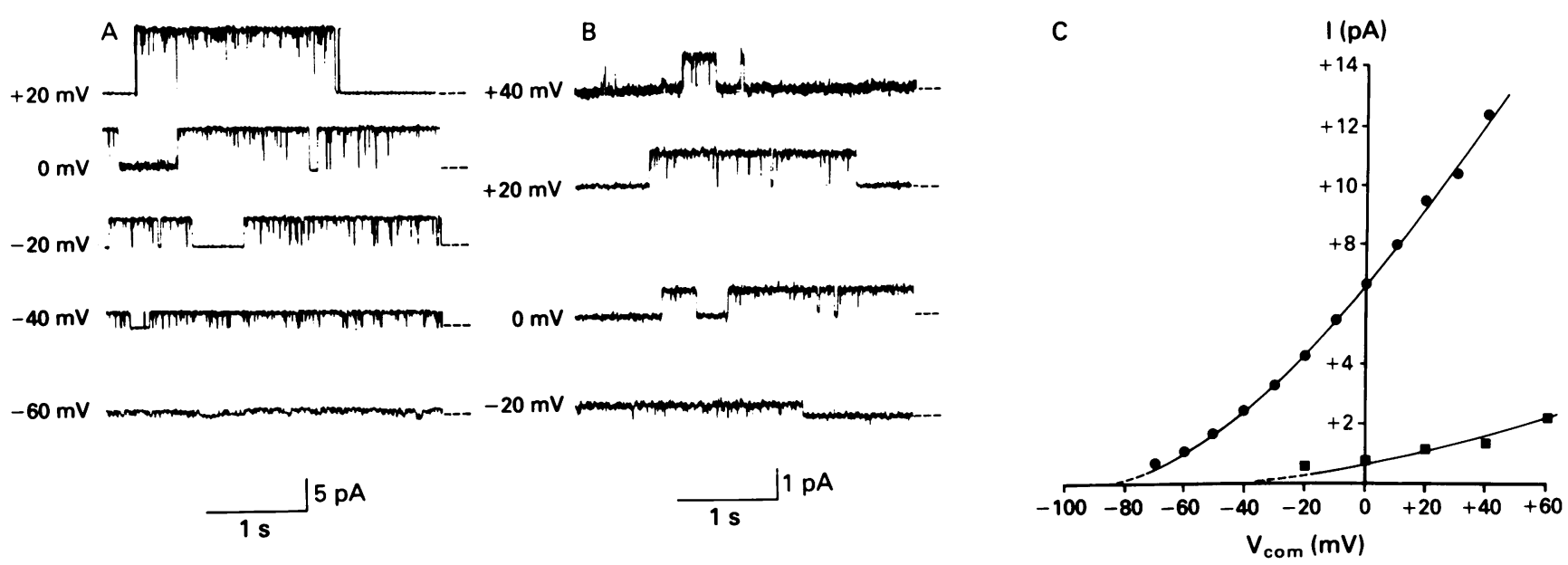

Figure $2: K^{+}$channel in an excised inside out patch of an $H G T-1$ cell. $(A)$ and $(B)$ show recordings at different holding potentials $\left(V_{\text {com }}\right)$ referenced to pipette interior (filled with $\mathrm{NaCl}$ solution). Recordings were obtained first with high $(145 \mathrm{mM}) K^{+}$solution $(A)$, then with low $(22 \cdot 5 \mathrm{mM}) K^{+}$solution $(B)$ in the bath. Dashed lines show zero current values. Upward current deflections show outward $K^{+}$flow from bath to pipette. $(C)$ shows current/voltage $\left(I / V_{\text {com }}\right)$ relations of the recordings in $(A)\left(145 \mathrm{mM}\right.$ bath $K^{+}$, closed circles $)$and $(B)\left(22 \cdot 5 \mathrm{mM}\right.$ bath $K^{+}$, closed squares $)$. Data fits and reversal potentials $\left(E_{\text {rev }}\right)$ obtained using the $G H K$ current and voltage equations.

tions were constructed by plotting the single channel current (equal to the difference between the open and closed channel currents) at each value of $\mathrm{V}_{\text {com. }}$. Single channel slope conductance was calculated at two values of $\mathrm{V}_{\text {com }}$ : (a) at -40 $\mathrm{mV}$, the cell membrane voltage measured in rabbit gastric glands with conventional microelectrodes and in rabbit parietal cells during whole cell current clamp studies, ${ }^{18} 19$ and (b) at infinite voltage (corresponding to the linear portion of the $I-V_{\text {com }}$ curve) where channel conductance was maximal.

Single channel open probability was determined using an analysis programme written in Quick Basic 4.0 (Microsoft, USA). A transition between the fully closed and fully open current levels occurred when the current crossed a threshold set halfway between these two states. Single channel open probability $\left(\mathbf{P}_{\mathrm{o}}\right)$ was calculated as:

$$
\mathbf{P}_{\mathrm{o}}=\left(\Sigma \mathrm{nt}_{\mathbf{n}}\right) / \mathrm{N}
$$

where $\mathbf{N}$ is the maximum number of channels seen to be open simultaneously during the recording (lasting 20-30 s), $n$ represents the state of the channels $(0=$ closed, $1=$ one channel open, etc), and $t_{n}$ is the time spent in state $n$. Channel kinetics were determined using pClamp software (Axon Instruments) and recordings from membrane patches in which only one channel was seen to be active. As channel activity usually occurred in bursts (Figs 1A and 2A), mean open and mean closed times, and open and closed time distribution histograms were obtained by restricting the analyses to individual bursts during 20-30 s of continuous recording. In most cases the first bin was ignored when fitting the distribution histograms (see Fig 4).

The sensitivity of $\mathrm{K}^{+}$channels to $\mathrm{Ca}^{2+}$ ions was determined in excised inside out patches by recording $\left(\mathrm{V}_{\text {com }}=0 \mathrm{mV}\right)$ first in the presence of the $\mathrm{Ca}^{2+}$ containing high $\mathrm{K}^{+}$bath solution, and then in the presence of a $\mathrm{Ca}^{2+}$ free high $\mathrm{K}^{+}$ solution containing the $\mathrm{Ca}^{2+}$ chelator ethyleneglycol-bis $\left(\beta\right.$-aminoethyl ether) $N, N^{\prime}$ tetra-acetic acid (EGTA, $5 \mathrm{mM}$ ).

The effect of $\mathrm{Ba}^{2+}$ ions, which block $\mathrm{K}^{+}$ channels in a variety of epithelial cell types, ${ }^{20-25}$ was assessed in excised inside out patches $\left(\mathrm{V}_{\text {com }}=\right.$ $0 \mathrm{mV}$ ) by replacing the high $\mathrm{K}^{+}$bath solution with a similar solution containing $5 \mathrm{mM} \mathrm{BaCl}_{2}$.

Additional experiments were performed to determine the effects of increasing the intracellular concentrations of cAMP and $\mathrm{Ca}^{2+}$ on $\mathrm{K}^{+}$ channel activity. With $\mathrm{NaCl}$ solution in the bath and high $\mathrm{K}^{+}$solution in the pipette, recordings were obtained from cell attached patches $\left(\mathrm{V}_{\text {com }}=\right.$ $0 \mathrm{mV}$ ) before and after the addition of $0.1 \mathrm{mM}$ dibutyryl cAMP (a permanent analogue of cAMP) or 6.7 $\mu \mathrm{M}$ A23187 (a Ca ${ }^{2+}$ ionophore). After the addition of agonist, $30 \mathrm{~s}$ segments of data were recorded at 1 minute intervals for 10 15 minutes.

MEASUREMENT OF INTRACELLULAR FREE CALCIUM CONCENTRATION

Intracellular free calcium concentration $\left(\left[\mathrm{Ca}^{2+}\right]_{\mathrm{i}}\right)$ was measured in HGT-1 cells loaded with the $\mathrm{Ca}^{2+}$ sensitive dye Fura-2. ${ }^{26}$ Cells grown on glass coverslips were loaded by incubating with culture medium (DMEM supplemented with $15 \mathrm{mM}$ HEPES, $2 \mathrm{mM}$ glutamine, $50 \mu \mathrm{g} / \mathrm{ml}$ penicillin, $50 \mu \mathrm{g} / \mathrm{ml}$ streptomycin, and $10 \%$ fetal calf serum) containing $10 \mu \mathrm{M}$ Fura-2/AM for 90 minutes in a humidified atmosphere of $5 \% \mathrm{CO}_{2} /$ $95 \%$ air at $37^{\circ} \mathrm{C}$. Coverslips were washed with buffered $\mathrm{NaCl}$ solution, mounted in a Sylgard lined chamber on the stage of a Nikon Diaphot microscope, and bathed in $\mathrm{NaCl}$ solution at room temperature $\left(20-22^{\circ} \mathrm{C}\right)$. Groups of about 5 cells were illuminated alternately with light of $350 \mathrm{~nm}$ and $380 \mathrm{~nm}$ wavelengths by means of a motor driven filter change wheel. The emitted fluorescence $(510(10 \mathrm{~nm}))$ with each excitation wavelength was monitored by photon counting (Newcastle Photometric Systems, Newcastle, UK). Fluorescence was corrected for background before calculation of the $350 \mathrm{~nm} / 380 \mathrm{~nm}$ emission ratio $(R) .\left[\mathrm{Ca}^{2+}\right]_{i}$ was calculated with reference to a standard calibration curve relating $\mathrm{Ca}^{2+}$ concentration to $\mathrm{R}$, which was constructed in vitro using $\mathrm{Ca}^{2+}$-EGTA buffers (Molecular Probes, Eugene, USA) yielding known $\mathrm{Ca}^{2+}$ 
concentrations (0-39.8 $\mu \mathrm{M})$ and containing $5 \mu \mathrm{M}$ Fura- 2 (free dye). $\mathrm{R}$ values were measured in $40 \mu \mathrm{l}$ droplets of each solution on a glass coverslip.

HGT-1 cells were exposed sequentially to zero, 3, 6.7, and 10, $\mu \mathrm{M}$ 4-bromo-A23187 (a non-fluorescent analogue of A23187) in $\mathrm{NaCl}$ solution containing $0.01 \%$ bovine serum albumin, which was included to prevent nonspecific binding of ionophore to the chamber. Bathing solutions were changed by careful aspiration, brief washing with the next solution, followed by addition of the same solution and refocusing on the designated area of cells before commencement of $\left[\mathrm{Ca}^{2+}\right]_{\mathrm{i}}$ measurement.

\section{STATISTICAL ANALYSIS}

Results are expressed as mean (standard error of the mean). Statistical analyses were performed using Student's $t$ test for paired or unpaired data as appropriate, and $\mathrm{p}$ values of $<0.05$ were considered significant.

\section{Results}

\section{$\left[{ }^{3} \mathrm{H}\right]$ OMEPRAZOLE BINDING}

A characteristic feature of the gastric parietal cell apical membrane is that it possesses omeprazole sensitive $\mathrm{H}^{+}, \mathrm{K}^{+}$-ATPase. ${ }^{27}$ When stimulated to secrete acid (for example, by histamine), additional $\mathrm{H}^{+}, \mathrm{K}^{+}$-ATPase units become operational as tubulovesicles rich in $\mathrm{H}^{+}, \mathrm{K}^{+}$-ATPase move from the cytoplasmic compartment to fuse with the apical membrane..$^{28}$ In HGT-1 cells, specific binding of $\left[{ }^{3} \mathrm{H}\right]$ omeprazole was significantly

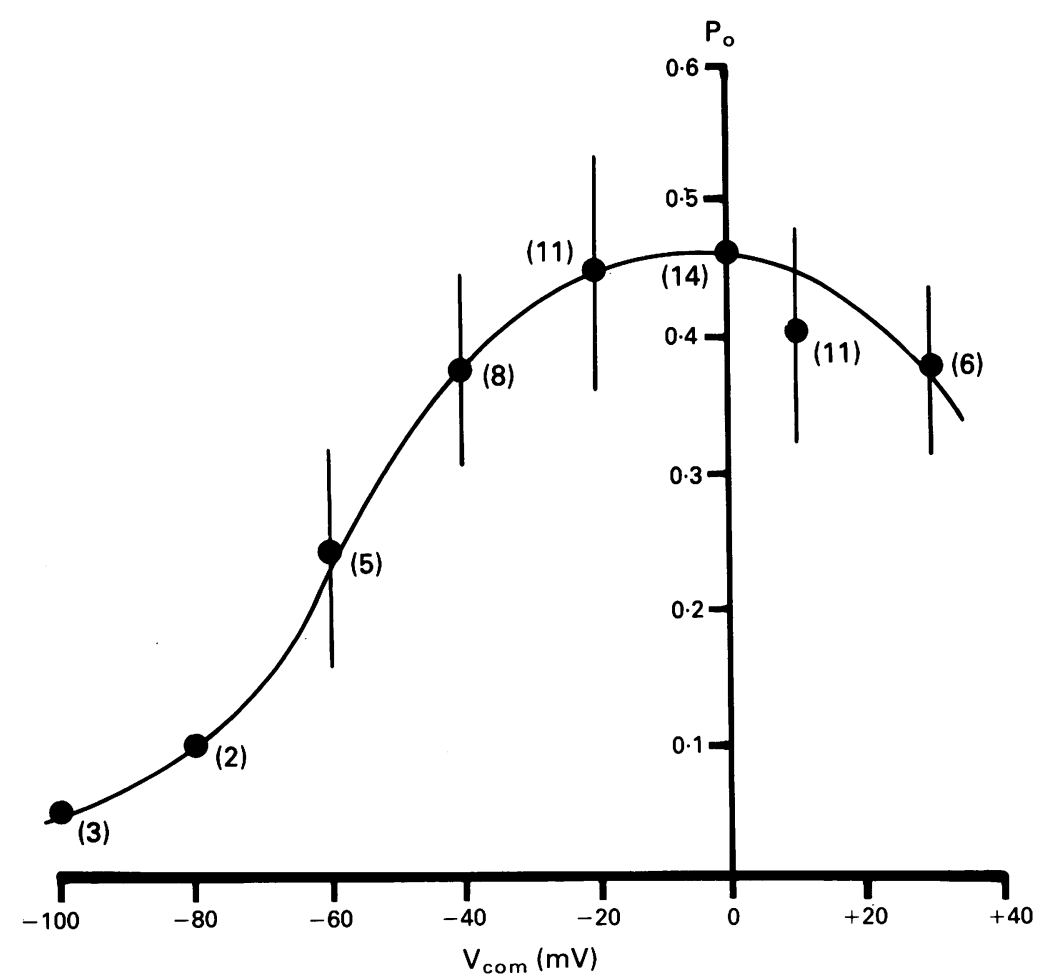

Figure 3: Relation between single channel open probability $\left(P_{\mathrm{o}}\right)$ and holding potential $\left(\mathrm{V}_{\text {com }}\right.$, referenced to pipette interior) of $K^{+}$channels in excised inside out patches of HGT-1 cells (high

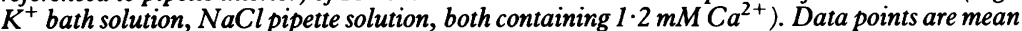
(SEM) values of $P_{\mathrm{o}}$ obtained from different patches (numbers shown in parentheses). The curve was drawn by hand. greater in the presence than in the absence of $1 \mathrm{mM}$ histamine $(4 \cdot 17(0 \cdot 45) \mathrm{pmol} / \mathrm{mg}$ cell protein $v 2.08(0.48) \mathrm{pmol} / \mathrm{mg}$ cell protein, $\mathrm{p}<0.05 ; \mathrm{n}=3$, measured in triplicate in both cases). In contrast, there was no evidence of specific binding of $\left[{ }^{3} \mathrm{H}\right]$ omeprazole to HT29-19A human colon cells in either the presence or the absence of histamine $(n=2$, measured in triplicate in both cases). These data show that the HGT-1 cell line, like gastric parietal cells, possesses specific omeprazole binding sites that may reflect $\mathrm{H}^{+}, \mathrm{K}^{+}$-ATPase moeities in the plasma membrane.

SINGLE CHANNEL CONDUCTANCE AND SELECTIVITY With high $\mathrm{K}^{+}$solution in the bath and $\mathrm{NaCl}$ solution in the pipette, single channel events were seen in subconfluent clumps of cells studied 4 to 8 days after culture, but never during days 9 to 15 after culture when cells seemed to be fully confluent. Under basal conditions, spontaneous channel activity was seen at $\mathrm{V}_{\text {com }}=0 \mathrm{mV}$ in 6 of $35(17 \%)$ cell attached patches and in 14 of 85 (16\%) excised inside out patches. One channel was seen in three of the six cell attached patches and in six of 14 inside out patches, while two or three channels were active simultaneously in the other patches.

Initial recordings were obtained in the cell attached configuration, and Fig $1 \mathrm{~A}$ shows the activity of a single $\mathrm{K}^{+}$channel over a range of pipette potentials in one experiment. Under these conditions (high $\mathrm{K}^{+}$bath solution, $\mathrm{NaCl}$ pipette solution), progressive depolarisation of the membrane patch (increasingly positive $\mathrm{V}_{\text {com }}$ ) increased the amplitude of the outward $\mathrm{K}^{+}$ currents, and Fig $1 B$ shows the I- $V_{\text {com }}$ curve for this channel. Data from six cell attached patches were fitted by the GHK equations. Mean single channel conductances at $\mathrm{V}_{\text {com }}=-40 \mathrm{mV}\left(\mathrm{g}_{-40}\right)$ and $\mathrm{V}_{\text {com }}=$ infinity $\left(\mathrm{g}_{\infty}\right)$ were $56(6) \mathrm{pS}$ and 155 (23) $\mathrm{pS}$ respectively, the mean value of $\mathrm{E}_{\text {rev }}$ was $-84 \cdot 2(0 \cdot 2) \mathrm{mV}$, and inward currents were not seen when $\mathrm{V}_{\text {com }}$ was varied between $-80 \mathrm{mV}$ and $-120 \mathrm{mV}$. These data show that the channel was highly selective for $\mathrm{K}^{+}$over $\mathrm{Na}^{+}$(mean $\mathrm{P}_{\mathrm{K}}: \mathrm{P}_{\mathrm{Na}}$ ratio 232 (19):1).

$\mathrm{K}^{+}$channel activity was also studied over a range of pipette potentials in a series of excised inside out patches, and Fig 2A shows results from a patch that contained a single channel (high $\mathrm{K}^{+}$bath solution, $\mathrm{NaCl}$ pipette solution). Similar to the cell attached configuration, $\mathrm{K}^{+}$ currents flowed outwards from the bath into the pipette, and increased during depolarisation of the membrane patch. The mean values of $g_{-40}$, $\mathrm{g}_{\infty}, \mathrm{E}_{\mathrm{rev}}$, and $\mathrm{P}_{\mathrm{K}}: \mathrm{P}_{\mathrm{Na}}$ ratio from 14 inside out patches were $62(6) \mathrm{pS}, 153(11) \mathrm{pS},-84 \cdot 8(0 \cdot 1)$ $\mathrm{mV}$ and 260 (11):1 respectively, and were not significantly different from those obtained in the cell attached configuration. Figure 2B shows smaller outward $\mathrm{K}^{+}$currents across one of four inside out patches when the $\mathrm{K}^{+}$concentration of the bath solution was decreased from $145 \mathrm{mM}$ to $22.5 \mathrm{mM}$ (with equimolar $\mathrm{Na}^{+}$replacement), and Fig $2 \mathrm{C}$ shows the effect of this change in bath $\mathrm{K}^{+}$concentration on the $\mathrm{I}-\mathrm{V}_{\text {com }}$ curves for the channel. Compared with $145 \mathrm{mM} \mathrm{K}{ }^{+}$in the bath solution, the mean values of $g_{\infty}, E_{r e v}$, and $P_{K}: P_{N a}$ 


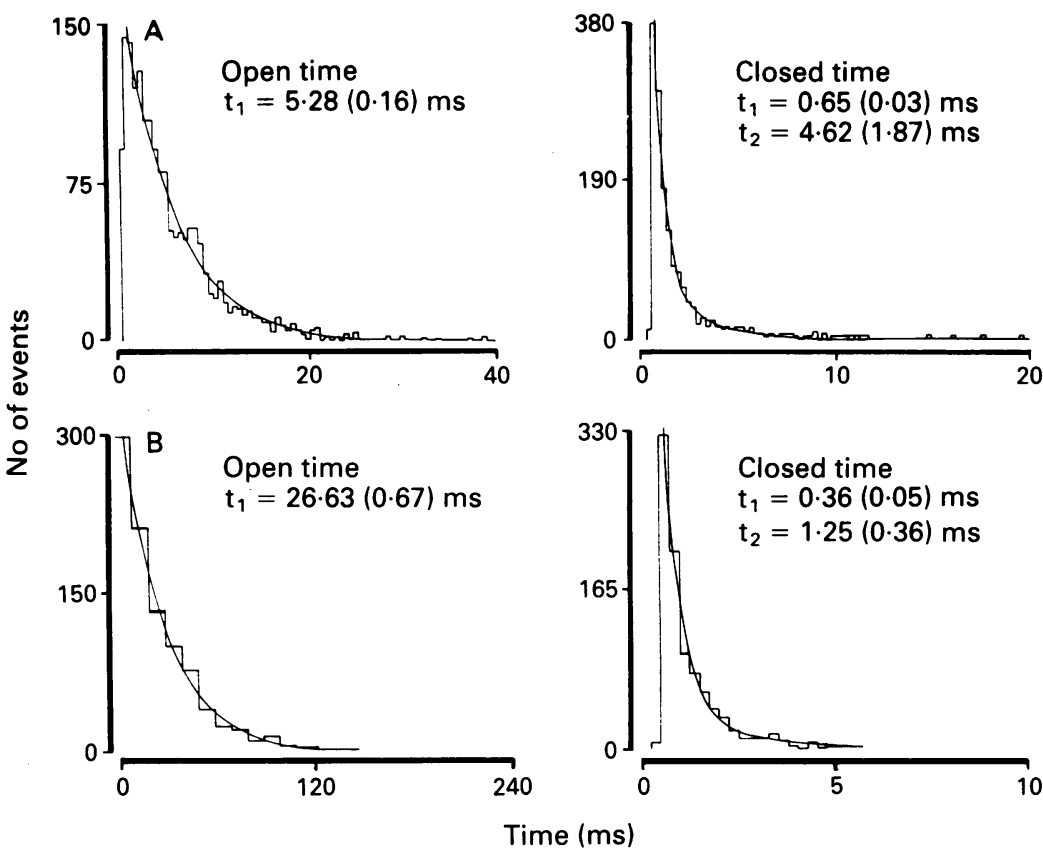

Figure 4: Open time and closed time histograms of $K^{+}$channels in cell attached $(A)$ and excised inside out $(B)$ patches of $H G T-1$ cells at $V_{\text {com }}=0 \mathrm{mV}$ (high $K^{+}$bath solution, $N a C l$ pipette solution in both configurations). Numbers of events for different open times and closed times are shown. Open time and closed time data were best fitted by single and double exponentials respectively. Time constants (mean (SEM)) for the open and closed states are shown in the Figure.

with $22.5 \mathrm{mM} \mathrm{K}^{+}$in the bath solution were all significantly $(\mathrm{p}<0.05)$ lower at $41(4) \mathrm{pS},-36.7$ $(0.6) \mathrm{mV}$, and $153(18): 1$ respectively $(\mathrm{n}=4)$. These data confirm that the plasma membrane of HGT- 1 cells contains high conductance channels which are highly selective for $\mathrm{K}^{+}$over $\mathrm{Na}^{+}$.

\section{VOLTAGE SENSITIVITY AND SINGLE CHANNEL} KINETICS

Figure 3 shows the relation between single channel open probability $\left(\mathrm{P}_{\mathrm{o}}\right)$ and pipette potential $\left(\mathrm{V}_{\text {com }}\right)$ in excised inside out patches $\left(\right.$ high $\mathrm{K}^{+}$

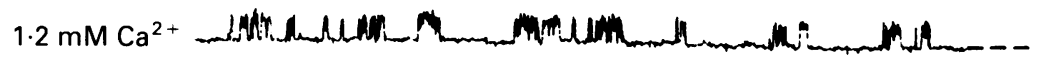

$0 \mathrm{mMCa}{ }^{2}$

+5 mM EGTA

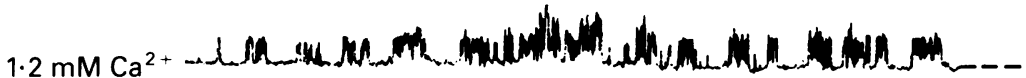

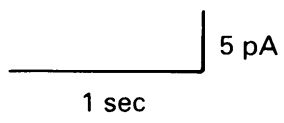

Figure 5: $\mathrm{Ca}^{2+}$ sensitivity of $\mathrm{K}^{+}$channels in excised inside out patch from an HGT-1 cell (high $K^{+}$bath solution, $N a C l$ pipette solution, $V_{\text {com }}=0 \mathrm{mV}$ ). Upper recording obtained when $1 \cdot 2 \mathrm{mMCa^{2+ }}$ present in the bath solution. Middle recording obtained with $0 \mathrm{mM} \mathrm{Ca}^{2+}$ and $5 \mathrm{mM} \mathrm{EGTA}$ in the bath solution, when channel activity virtually disappeared. Lower recording shows return of channel activity after restoring $1 \cdot 2 \mathrm{mM} \mathrm{Ca}{ }^{2+}$ to the bath solution. Dashed lines show zero current values. Upward curreni deflections show outward $K^{+}$flow from bath to pipette. bath solution, $\mathrm{NaCl}$ pipette solution). Open probability increased almost fivefold during depolarisation of the membrane from $-80 \mathrm{mV}$ to $-20 \mathrm{mV}$, showing that the channels were voltage dependent across the voltage range normally encountered within epithelial cells. Further depolarisation of the membrane to nonphysiological voltages $(0 \mathrm{mV}$ to $+40 \mathrm{mV})$ caused a decrease in open probability that was particularly noticeable $(56 \%)$ in four patches (data not shown). The cause of this decrease in open probability is unclear, but it is possible that over this range of depolarising voltages, $\mathrm{Ca}^{2+}$ at high concentration ( $1.2 \mathrm{mM}$ in the bath) blocked the channel at a site that normally binds $\mathrm{Ba}^{2+}$ (see below), as seen with rabbit skeletal muscle $\mathrm{K}^{+}$ channels incorporated into planar lipid bilayers. ${ }^{29}$

Preliminary examination of channel recordings obtained from cell attached patches (for example, Fig 1A) showed rapid current transitions, channels opening and closing for comparatively short periods. In contrast, with inside out patches (for example, Fig 2A) channels generally spent longer in the open state at equivalent values of $\mathrm{V}_{\text {com }}$, while closed times were similar to those seen in cell attached patches (see below). The kinetics of bursts of channel activity were assessed by obtaining open and closed time histograms for membrane patches containing a single channel. Figure 4A shows typical histograms from one of four cell attached patches, which showed (at $V_{\text {com }}=0 \mathrm{mV}$ ) one open time constant (mean value $6.7(1.0) \mathrm{ms}$ ) and two closed time constants (mean values $0.7(0.2) \mathrm{ms}$ and $4 \cdot 2(1 \cdot 1) \mathrm{ms})$, with mean open and closed times of $6.8(0.7) \mathrm{ms}$ and $3.0(0.5) \mathrm{ms}$ respectively. Figure 4B shows histograms from one of five inside out patches, which again showed (at $\mathrm{V}_{\text {com }}=0 \mathrm{mV}$ ) one open time constant (mean value $31 \cdot 1(10 \cdot 0) \mathrm{ms})$ and two closed time constants (mean values $0 \cdot 4(0 \cdot 1) \mathrm{ms}$ and $1 \cdot 8(0 \cdot 3)$ ms), with mean open and closed times of 30.4 $(8 \cdot 1) \mathrm{ms}$ and $1 \cdot 5(0 \cdot 2) \mathrm{ms}$ respectively. The long closed intervals ( $>35 \mathrm{~ms}$ ) seen between bursts would probably provide a third closed time constant, but there were insufficient for histogram analysis. It should be noted that the mean open time was significantly longer and the mean closed time was significantly shorter in the inside out patches than in the cell attached patches $(30.4(8.1) \mathrm{ms} v 6.8(0.7) \mathrm{ms}, \mathrm{p}<0.05$ and 1.5 $(0.2) \mathrm{ms} v 3.0(0.5) \mathrm{ms}, \mathrm{p}<0.05$ respectively). These differences may reflect the higher concentration of $\mathrm{Ca}^{2+}$ presented to the cytosolic surface of the membrane in the inside out configuration (see below).

\section{CALCIUM SENSITIVITY}

To determine the $\mathrm{Ca}^{2+}$ sensitivity of $\mathrm{K}^{+}$channels in inside out patches, recordings were attempted after the $\mathrm{Ca}^{2+}$ containing $(1 \cdot 2 \mathrm{mM})$ high $\mathrm{K}^{+}$bath solution was replaced with either a $\mathrm{Ca}^{2+}$ free high $\mathrm{K}^{+}$solution containing $5 \mathrm{mM}$ EGTA $\left(\mathrm{Ca}^{2+}\right.$ concentration $\left.10 \mathrm{nM}\right)$ or an EGTA buffered high $\mathrm{K}^{+}$solution containing $1 \mu \mathrm{M}$ $\mathrm{Ca}^{2+}$. In nearly all cases, these manoeuvres caused patches to be lost almost immediately. Consequently, $\mathrm{Ca}^{2+}$ sensitivity of the $\mathrm{K}^{+}$chan- 


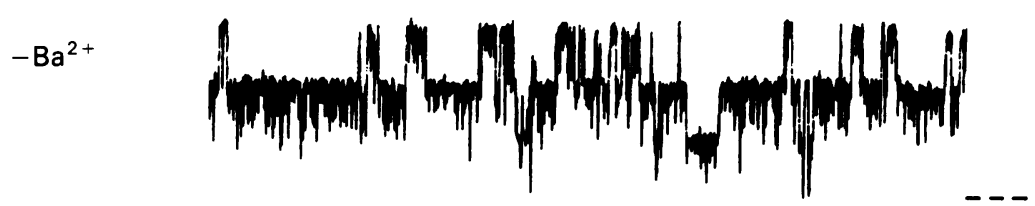

$+5 \mathrm{mMBa}^{2+}$

$-\mathrm{Ba}^{2+}$
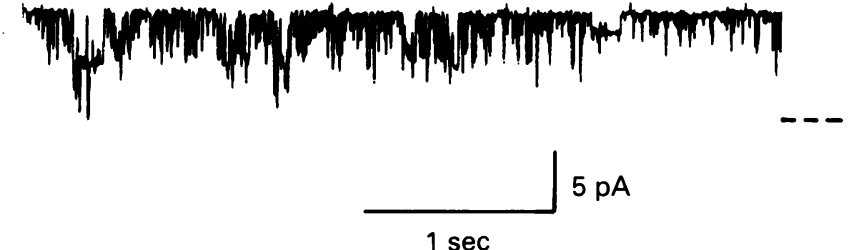

$1 \mathrm{sec}$

Figure 6: $B a^{2+}$ sensitivity of $\mathrm{K}^{+}$channels in excised inside out patch from an $H G T-1$ cell (high $K^{+}$bath solution, $N a C l$ pipette solution $V_{\text {com }}=0 \mathrm{mV}$ ). Upper recording obtained in the absence of $\mathrm{Ba}^{2+}$ and three channels were active in the patch. Middle recording obtained with $5 \mathrm{mM}$ $B a^{2+}$ in the bath solution, when channel activity was almost abolished. Lower recording shows return of channel activity after washing out $\mathrm{Ba}^{2+}$. Dashed lines show zero current values.

Upward current deflections show outward $K^{+}$flow from bath to pipette.

nel was examined in only two inside out patches at $\mathrm{V}_{\text {com }}=0 \mathrm{mV}$. Figure 5 shows that in one patch, replacing the $\mathrm{Ca}^{2+}$ containing high $\mathrm{K}^{+}$bath solution with the $\mathrm{Ca}^{2+}$ free high $\mathrm{K}^{+}$solution decreased $P_{0}$ from 0.200 to 0.005 and returning to $1.2 \mathrm{mM} \mathrm{Ca}{ }^{2+}$ increased $P_{0}$ to 0.359 . In the other patch, $\mathrm{Ca}^{2+}$ removal decreased $\mathrm{P}_{\mathrm{o}}$ from 0.396 to 0.017 . Thus, although it was not possible to obtain a detailed analysis of the relation between $P_{o}$ and $V_{\text {com }}$ at different $\mathrm{Ca}^{2+}$ concentrations, the available data show that under these experimental conditions, $\mathrm{K}^{+}$channels were sensitive to changes in the concentration of $\mathrm{Ca}^{2+}$ bathing the cytosolic surface of the membrane.

\section{BARIUM SENSITIVITY}

The effect $\mathrm{Ba}^{2+}$ ions (final bath concentration $5 \mathrm{mM}$ ) on $\mathrm{K}^{+}$channel activity was examined in inside out patches $\left(V_{\text {com }}=0 \mathrm{mV}\right)$. Figure 6 shows
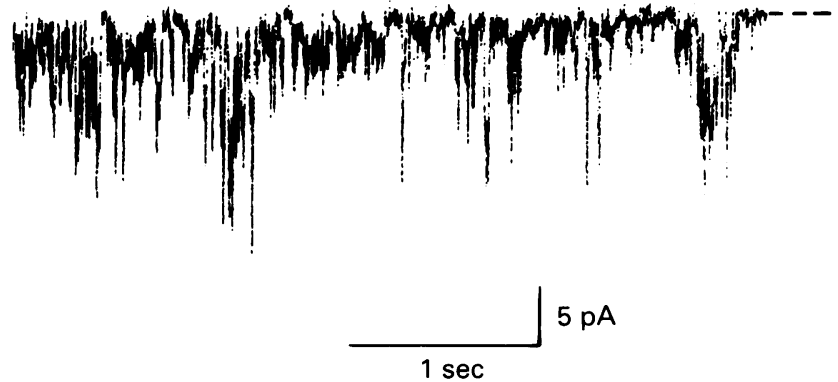

Figure 7: Effect of $A 23187$ on $\mathrm{K}^{+}$channel activity in cell attached patch of an HGT-1 cell (NaCl bath solution, high $\mathrm{K}^{+}$pipette solution, $V_{\text {com }}=0 \mathrm{mV}$ ). Upper recording obtained in basal (quiescent) state. Lower recording obtained four minutes after the addition of $6 \cdot 7 \mu M$ A23187, when several channels were activated in the patch. Dashed lines show zero current values. Downward current deflections show inward $K^{+}$flow from pipette to cell. recordings from one patch in which $\mathrm{Ba}^{2+}$ inhibited $\mathrm{K}^{+}$channel activity, while channel activity returned almost to the initial level after washing out $\mathrm{Ba}^{2+}$. In three patches, $\mathrm{Ba}^{2+}$ decreased $P_{o}$ from $0.392(0.081)$ to $0.030(0.024)$ $(\mathrm{p}<0.05)$.

\section{EFFECTS OF DIBUTYRYL CAMP AND A23187}

With $\mathrm{NaCl}$ solution in the bath and high $\mathrm{K}^{+}$ solution in the pipette $\left(\mathrm{V}_{\text {com }}=0 \mathrm{mV}\right)$, the addition of $0.1 \mathrm{mM}$ dibutyryl cAMP failed to elicit $\mathrm{K}^{+}$channel activity in 17 cell attached patches while recording for periods of up to 15 minutes, suggesting that $\mathrm{K}^{+}$channels in HGT-1 cells are not regulated by intracellular cAMP.

In contrast, the addition of $6.7 \mu \mathrm{M}$ A23187 stimulated $\mathrm{K}^{+}$channel activity (generally within four minutes, see Fig 7) in five of $24(21 \%)$ quiescent cell attached patches, $P_{0}$ increasing to $0.218(0.097)$ at $V_{\text {com }}=0 \mathrm{mV}$. As shown in Fig 7, channel kinetics under conditions that produced inward current flow $(\mathrm{NaCl}$ solution in the bath and high $\mathrm{K}^{+}$solution in the pipette) differed from those seen during outward current flow (see Fig 1), and it is possible that channels were not activated sufficiently to produce sustained bursts of openings when $\mathrm{NaCl}$ solution was present in the bath. Although the reason for this is unclear, it may at least partly reflect the voltage sensitivity of the $\mathrm{K}^{+}$channels (see Fig 3). Thus, irrespective of other intracellular regulatory factors, $\mathrm{K}^{+}$ channel activity will be lower with $\mathrm{NaCl}$ solution in the bath (that is, at the resting potential of the cell membrane) than with high $\mathrm{K}^{+}$solution in the bath (that is, when cell membrane potential is zero). It seems extremely unlikely that the inward currents reflected $\mathrm{Cl}^{-}$movement from the cell to the pipette by $\mathrm{Ca}^{2+}$-activated $\mathrm{Cl}^{-}$ channels, as the mean single channel current at $\mathrm{V}_{\text {com }}=0 \mathrm{mV}(5.5(1.3) \mathrm{pA}, \mathrm{n}=5)$ was considerably greater than that (approximately $1 \mathrm{pA}$ at $\mathrm{V}_{\text {com }}=0 \mathrm{mV}$ ) flowing through cAMP activated $\mathrm{Cl}^{-}$channels in cell attached patches of HGT-1 cells with $\mathrm{NaCl}$ solution in both the bath and the pipette. ${ }^{12}$ Taken together, these findings suggest that the inward currents in A23187-stimulated cells reflected $\mathrm{K}^{+}$flow from pipette to cell through high conductance $\mathrm{K}^{+}$channels.

\section{INTRACELLULAR CALCIUM CONCENTRATION IN} HGT-1 CELLS

As mentioned above, it was not possible to perform a detailed study of the $\mathrm{Ca}^{2+}$ sensitivity of $\mathrm{K}^{+}$channels in excised inside out patches. Because $6.7 \mu \mathrm{M}$ A23187 activated $\mathrm{K}^{+}$channels in cell attached patches when cells were bathed in $\mathrm{NaCl}$ solution, we measured the changes in $\left[\mathrm{Ca}^{2+}\right]_{\mathrm{i}}$ that occurred under identical conditions in response to increasing concentrations of A23187. As shown in Fig 8, basal values of $\left[\mathrm{Ca}^{2+}\right]_{\mathrm{i}}$ were low before the addition of 4-bromoA23187 (14 (3 nM)). The ionophore, however, stimulated dose dependent increases in $\left[\mathrm{Ca}^{2+}\right]_{i}$, steady state values being achieved within four to five minutes. Intracellular $\mathrm{Ca}^{2+}$ concentration increased to 248 (30) $\mathrm{nM}$ (range: 166-301 nM) after the addition of $6.7 \mu \mathrm{M}$ 4-bromo-A23187, which suggests that $6.7 \mu \mathrm{M}$ A23187 stimulated 


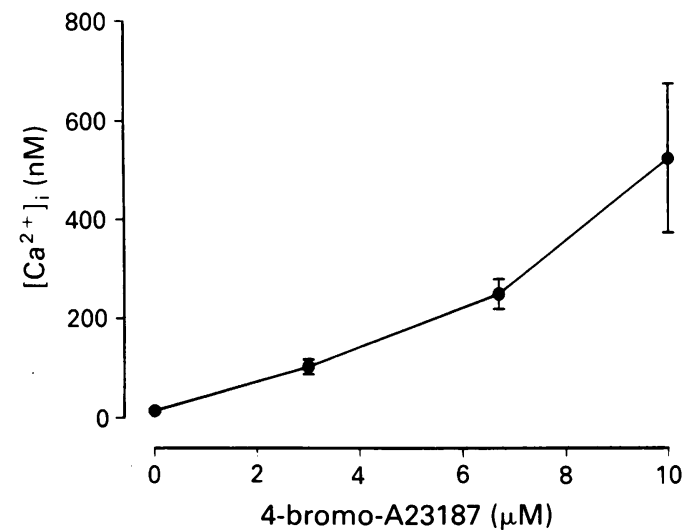

Figure 8: Effect of 4-bromo-A23187 on intracellular $\mathrm{Ca}^{2+}$ concentration $\left(\left[\mathrm{Ca}^{2+}\right]_{\mathrm{i}}\right)$ in $\mathrm{HGT}-1$ cells. Results are shown as mean $(S E M)(n=4$ for $0,3,6 \cdot 7$, and $10 \mu M$ 4-bromoA23187).

$\mathrm{K}^{+}$channel activity in cell attached patches (see Fig 7) by increasing $\left[\mathrm{Ca}^{2+}\right]_{\mathrm{i}}$ to similar values.

\section{Discussion}

EVIDENCE FOR $\mathrm{H}^{+}, \mathrm{K}^{+}$-ATPASE IN HGT-1 CELLS HGT- 1 cells share a number of characteristics with acid secreting gastric parietal cells (for example, $\mathrm{H}_{2}$ receptors, histamine activated adenylate cyclase, cAMP mediated $\mathrm{Cl}^{-}$ channels), but previous studies have not evaluated their $\mathrm{H}^{+}, \mathrm{K}^{+}$-ATPase content. With $\left[{ }^{3} \mathrm{H}\right]$ omeprazole as a probe for $\mathrm{H}^{+}, \mathrm{K}^{+}$-ATPase, we found that HGT-1 cells exhibited a significant degree of specific $\left[{ }^{3} \mathrm{H}\right]$ omeprazole binding, which increased $100 \%$ in the presence of histamine. Although histamine stimulates the incorporation of $\mathrm{H}^{+}, \mathrm{K}^{+}$-ATPase rich cytoplasmic tubulovesicles into the apical membrane in parietal cells, ${ }^{3031}$ it is unclear whether a similar phenomenon occurred in HGT-1 cells as they have been shown to be devoid of secretory organelles. ${ }^{11}$ It is worth noting at this point, however, that although the HGT-1 cell line shows morphological heterogeneity, seven clonal cell lines each with homogeneous morphology have been identified. ${ }^{13}$ Two of these clones exhibited activities of histamine induced cAMP production that were 2-3 times greater than those in the other clones or in the parent HGT-1 line despite the absence of interclonal variability in the affinity of the clones for histamine. ${ }^{13}$ Thus it seems that the HGT-1 cell line contains subpopulations of epithelial cells, two of which may have a comparatively high density of $\mathrm{H}_{2}$ receptors or a particularly efficient interaction between the $\mathrm{H}_{2}$ receptor and adenylate cyclase. These two clones (clones 3 and 6, see ref 13) may bear the closest resemblance to gastric parietal cells and contain secretory organelles within their cytoplasm, which become incorporated into the cell membrane in the presence of histamine. Furthermore, histamine has been shown to trigger cAMP dependent phosphorylation of a $27 \mathrm{kDa}$ phosphoprotein, which is restricted to the same low speed fraction of parietal cells that contains increased $\mathrm{H}^{+}, \mathrm{K}^{+}$ATPase activity after histamine stimulation. ${ }^{32}$ The ability of histamine to increase $\left[{ }^{3} \mathrm{H}\right]$ omepra- zole binding in HGT-1 cells may therefore reflect the presence of $\mathrm{H}^{+}, \mathrm{K}^{+}$-ATPase units within the plasma membrane whose affinity for $\left[{ }^{3} \mathrm{H}\right]$ omeprazole is increased by cAMP dependent phosphorylation of the enzyme protein.

\section{HGT- 1 CELLS EXPRESS $\mathrm{K}^{+}$CHANNELS}

There is strong evidence that $\mathrm{K}^{+}$channels exist in both the apical and basolateral membranes of gastric parietal cells. In frog stomach and isolated rabbit gastric glands, external $\mathrm{K}^{+}$is an absolute requirement for acid secretion. ${ }^{33-36} \mathrm{At}$ the external (luminal) surface of the apical membrane, $\mathrm{K}^{+}$ions participate in a $\mathrm{H}^{+}, \mathrm{K}^{+}$-ATPase mediated exchange with $\mathrm{H}^{+}$ions, although whether the initial apical $\mathrm{K}^{+}$exit step is electroneutral or channel mediated remains controversial. ${ }^{16-8}$ If it is assumed that basolateral $\mathrm{Na}^{+}-\mathrm{K}^{+}$ pump activity increases during acid secretion, $\mathrm{K}^{+}$entering the cell must recycle across the basolateral membrane to maintain intracellular $\mathrm{K}^{+}$concentration, and a basolateral conductance has been shown in Necturus and frog oxyntic cells. ${ }^{9} 1025373$ This study shows that HGT-1 cells express $\mathrm{K}^{+}$channels, and we now consider their comparatively low prevalence, likely site of origin, and characteristics.

We saw $\mathrm{K}^{+}$channel activity in $17 \%$ of cell attached and inside out patches from HGT-1 cells in the absence of acid secretory agonists. This fairly low level of detection suggests that either $\mathrm{K}^{+}$channels were present at low density in the plasma membrane, or that $\mathrm{K}^{+}$channels were limited to a small subpopulation of cells within the HGT-1 cell line. It should be noted that $\mathrm{K}^{+}$ channels were seen after four to eight days of culture when cells were subconfluent, but never beyond eight days when the cells were fully confluent. This suggests that either the $\mathrm{K}^{+}$ channel bearing cells were overgrown by other cell types when true confluency was achieved, or confluency was associated with full polarisation of the cells and movement of $\mathrm{K}^{+}$channels to the basolateral membrane, which was inaccessible to the patch pipette. The fact that the prevalence of $\mathrm{K}^{+}$channels in cell attached patches was similar when A23187 stimulated cells were bathed in $\mathrm{NaCl}$ solution $(21 \%)$ and non-stimulated cells were bathed in high $\mathrm{K}^{+}$solution $(17 \%)$, suggests that the high external $\mathrm{K}^{+}$concentration depolarised the cells and caused a passive increase in $\left[\mathrm{Ca}^{2+}\right]_{\mathrm{i}}$.

Our results show that the $\mathrm{K}^{+}$channel expressed by HGT-1 cells is $\mathrm{Ca}^{2+}$ dependent, voltage and $\mathrm{Ba}^{2+}$ sensitive, and possesses complex gating characteristics with one open state and at least two closed states. Single channel conductance was high (about $155 \mathrm{pS}$ ) at infinite voltage but considerably lower (about $60 \mathrm{pS}$ ) at $-40 \mathrm{mV}$, the cell membrane voltage measured in rabbit parietal cells. ${ }^{18}{ }^{19}$ Basolateral $\mathrm{K}^{+}$conductance is the main determinant of basolateral membrane voltage in Necturus oxyntic cells, ${ }^{37}$ and the basolateral membrane of frog oxyntic cells possesses a substantial $\mathrm{Ba}^{2+}$-sensitive $\mathrm{K}^{+}$conductance, which increases in the presence of histamine. ${ }^{910}$ Single channel studies have shown two types of basolateral $\mathrm{K}^{+}$channel (one activated by cAMP, the other by $\mathrm{Ca}^{2+}$ ) in Necturus oxyntic cells. ${ }^{38}$ 
Frog oxyntic cells also possess two types of inward rectifying basolateral $\mathrm{K}^{+}$channel (a) a $\mathrm{Ca}^{2+}$ activated, $61 \mathrm{pS}$ channel that is voltage independent, $\mathrm{Ca}^{2+}$ sensitive and $\mathrm{Ba}^{2+}$ sensitive, and (b) a cAMP-activated, $30 \mathrm{pS}$ channel that is $\mathrm{Ca}^{2+}$ insensitve. ${ }^{25}$ In contrast, it is not clear if the basolateral membrane voltage in mammalian (rabbit) parietal cells reflects $\mathrm{Cl}^{-}, \mathrm{K}^{+}$, or both types of channel. ${ }^{19}$ Although the properties of basolateral $\mathrm{K}^{+}$channels in oxyntic cells seem to be species dependent, $\mathrm{K}^{+}$channels in HGT-1 cells share some characteristics (for example, similar conductance within the physiological voltage range, activation by $\mathrm{Ca}^{2+}$, and sensitivity to $\mathrm{Ca}^{2+}$ and $\mathrm{Ba}^{2+}$ ) with the $61 \mathrm{pS} \mathrm{K}^{+}$channel identified in amphibian oxyntic cells. ${ }^{25} 38$

Acid secretion by gastric parietal cells is regulated by several receptor mediated neurohumoral agonists including histamine, which increases the intracellular concentrations of both cAMP and $\mathrm{Ca}^{2+} .{ }^{39} 40$ Indeed, concomitant increases in intracellular cAMP (induced by adding dibutyryl cAMP) and $\mathrm{Ca}^{2+}$ (induced by adding carbachol) have a potentiating effect on acid accumulation in isolated canine parietal cells. ${ }^{41}$ It is now clear that HGT-1 cells resemble parietal cells in possessing $\mathrm{H}_{2}$ receptors and specific omeprazole binding sites (presumably $\mathrm{H}^{+}, \mathrm{K}^{+}$-ATPase units). The additional presence of cAMP dependent $\mathrm{Cl}^{-}$channels and $\mathrm{Ca}^{2+}$ dependent $\mathrm{K}^{+}$channels in this gastric cell line may provide an opportunity to study possible interactions between these two types of channel in response to a variety of acid secretory agonists.

We are grateful to Dr C L Laboisse (Laboratoire de Biologie et de We are grateful to Dr C L Laboisse (Laboratoire de Biologie et de Physiologie des Cellules Digestives, U 239 INSERM, Paris) for
supplying the HGT-1 cell line, and to Astra Pharmaceuticals Ltd supplying the HGT-l cell line, and to Astra Pharmaceuticals Ltd for supplying radiolabelled omeprazole. The single channel analy-
sis programme was a gift of $\mathrm{Dr} M$ Hunter (Department of sis programme was a gift of Dr M Hunter (Department of
Physiology, University of Leeds). This study was supported in part by a grant from the Royal Society.

1 Wolosin JM, Forte JG. Stimulation of the oxyntic cell triggers olosin JM, Forte JG. Stimulation of the oxyntic cell triggers $\mathrm{K}^{+}$and $\mathrm{Cl}^{-}$conductances in apical $\mathrm{H}^{+}$,
brane. Am $\mathcal{F}$ Physiol 1984; 246: C537-45.

2 Malinowska DH. $\mathrm{Cl}^{-}$channel blockers inhibit acid secretion in rabbit parietal cells. Am $\mathcal{F}$ Physiol 1990; 259: G536-43.

3 Ganser AL, Forte JG. $\mathrm{K}^{+}$-stimulated ATPase in purified microsomes of bullfrog oxyntic cells. Biochim Biophys Acta 1973; 307: 169-80.

4 Sachs G, Chang H, Rabon E, Schackmann R, Levin M, Saccomani $G$. A non-electrogenic $\mathrm{H}^{+}$pump in plasma membrane of hog stomach. $\mathcal{F}$ Biol Chem 1976; 251: 7690-8.

5 Forte JG, Lee HC. Gastric adenosine triphosphatases. Gastroenterology 1977; 73: 921-6.

6 Wolosin JM, Forte JG. Kinetic properties of the $\mathrm{KCl}$ transport at the secreting apical membrane of the oxyntic cell. $\mathcal{F} \mathrm{Membr}$ Biol 1983; 71: 195-207.

7 Perez A, Blissard D, Sachs G, Hersey SJ. Evidence for a chloride conductance in secretory membrane of parietal cells. Am F Physiol 1989; 256: G299-305.

8 Cuppoletti J, Sachs G. Regulation of gastric acid secretion by modulation of a chloride conductance. $\mathcal{F}$ Biol Chem 1984; 159: 14952-9.

9 Schettino T, Trischitta F. Transport properties of the basolateral membrane of the oxyntic cells in frog fundic gastric mucosa. Pflügers Arch 1989; 404: 469-76.

10 Debellis L, Curci S, Frömter E. Effect of histamine on the basolateral $\mathrm{K}^{+}$conductance of frog stomach oxyntic cells and surface epithelial cells. Am f P hysiol 1990; 258: G631-6.

11 Laboisse CL Auron Cheret A-M, Potet F. Characterization of a newly established human gastric cancer cell line HGT-1 bearing histamine $\mathrm{H}_{2}$-receptors. Cancer Res 1982; 42: 1541-8.
12 Sandle GI, Fraser G, Long S, Warhurst G. A cAMP-activated chloride channel in the plasma membrane of cultured human chloride channel in the plasma membrane of cultured h
gastric cells (HGT-1). Pflügers Arch 1990; 417: 259-63.

13 Cheret A-M, Laboisse CL, Roumagnac I, Augeron C, Lewin MJM. Highly histamine-responsive clones from the human gastric adenocarcinoma cell line HGT-1. Agents Actions
1985; 17: 436-40.

14 Lowry OH, Roseborough NJ, Farr AL, Randall RJ. Protein measurement with the Folin phenol reagent. $\mathcal{F}$ Biol Chem 1951; 193: 265-75.

15 Hamill OP, Marty A, Neher E, Sackmann B, Sigworth FJ. Improved patch clamp techniques for high-resolution current recording from cells and cell-free membrane patches. Pfiugers Arch 1981; 391: 85-100.

16 Goldman DE. Potential, impedance and rectification in membranes. F Gen Physiol 1943; 27: 37-60.

17 Hodgkin AL, Katz B. The effect of sodium on the electrical activity of the giant axon of the squid. $\mathcal{F}$ Physiol 1949; 108: activity

18 Schettino T, Köhler M, Frömter E. Membrane potentials of individual cells of isolated gastric glands of rabbit. Pflügers Arch 1985; 405: 58-65.

19 Sakai H, Okada Y, Morii M, Takeguchi N. Anion and cation channels in the basolateral membrane of rabbit parietal cells. Pfiugers Arch 1989; 414: 185-92.

20 Morris AP, Gallacher DV, Lee JAC. A large conductance, voltage- and calcium-activated $\mathrm{K}^{+}$channel in the basolateral membrane of rat enterocytes. FEBS Letters 1986; 206: 87-92.

21 Gögelein H, Greger R, Schlatter E. Potassium channels in the basolateral membrane of the rectal gland of Squalus acanthias. Regulation and inhibitors. Pflügers Arch 1987; 409: 107-13.

22 Kunzelmann K, Pavenstädt H, Greger R. Characterization of potassium channels in respiratory cells. II. Inhibitors and regulation. Pflügers Arch 1989; 414: 297-303

23 Giebisch G, Hunter M, Kawahara K. Apical potassium channels in Amphiuma diluting segment: effect of barium. f Physiol 1990; 420: 313-23.

24 Fraser G, McNicholas CM, Brown CDA, Sandle GI. Highconductance basolateral potassium channels in intact crypts from rat duodenum. F Physiol 1991; 434: $31 \mathrm{P}$.

25 Mieno H, Kaiiyama G. Electrical characteristics of inwardrectifying $\mathrm{K}^{+}$channels in isolated bullfrog oxyntic cells. Am F Physiol 1991; 261: G206-12.

26 Grynkiewicz G, Poenie $M$, Tsien RY. A new generation of $\mathrm{Ca}^{2+}$ indicators with greatly improved fluorescence proper$\mathrm{Ca}^{2+}$ indicators with greatly improved
ties. $\mathcal{F}$ Biol Chem $1985 ; 260: 3440-50$.

27 Fellenius E, Berglindh T, Sachs G, et al. Substituted benzimidazoles inhibit gastric acid secretion by blocking $\left(\mathbf{H}^{+}+\right.$ $\mathrm{K}^{+}$) ATPase. Nature 1981; 290: 159-61.

28 Forte JG, Wolosin JM. HCl secretion by the gastric oxyntic cell. In: Johnson LR, ed. Physiology of the gastrointestinal tract. 2nd Ed. New York: Raven Press, 1987: 853-63.

29 Vergara C, Latorre R. Kinetics of $\mathrm{Ca}^{2+}$-activated $\mathrm{K}^{+}$channels from rabbit muscle incorporated into planar bilayers. $\mathcal{F}$ Gen Physiol 1983; 82: 543-68.

30 Ito S, Schofield GC. Studies on the depletion and accumulation of microvilli and changes in the tubulovesicular compartment of mouse parietal cells in relation to gastric acid ment of mouse parietal cells in rela

31 Forte TM, Machen TE, Forte JG. Ultrastructure and physiological changes in piglet oxyntic cells associated with logical changes in piglet oxyntic cells associated with secretory function: A membrane-roenterology 1975; 69: 1208-22.

32 Chew CS, Brown MR. Histamine increases phosphorylation of 27- and 40-kDa parietal cell proteins. Am $\mathcal{F}$ Physiol 1987; 253: G823-9.

33 Davis TL, Rutledge JR, Keesee DC, Bajandas FJ, Rehm WS Acid secretion, potential and resistance of frog stomach in $\mathrm{K}^{+}$-free solutions. Am $\mathcal{F}$ P hysiol 1965; 209: 146-52.

34 Rehm WS, Sanders SS, Rutledge JR, et al. Effect of removal of external $\mathrm{K}^{+}$on frog's stomach in $\mathrm{Cl}^{-}$-free solution. $\mathrm{Am} \mathcal{F}$ Physiol 1966; 210: 689-93.

35 Sanders SS, Noyer DH, Spangler SG, Rehm WS. Demonstration of a barium-potassium antagonism on lumen side of in vitro frog stomach. Am $\mathcal{F}$ Physiol 1973; 224: 1254-9.

36 Koelz HR, Sachs G, Berglindh T. Cation effects on acid secretion in rabbit gastric glands. Am F Physiol 1981; 241 G431-42.

37 Demarest JR, Machen TE. Microelectrode measurements from oxyntic cells in intact Necturus gastric mucosa. Am $\mathcal{F}$ Physiol 1985; 249: C535-40.

38 Ueda S, Loo DDF, Sachs G. Regulation of $\mathrm{K}^{+}$channels in the basolateral membrane of Necturus oxyntic cells. $\mathcal{f} \mathrm{Membr}$ Biol 1987; 97: 31-41.

39 Chew CS, Hersey SJ, Sachs G, Berglindh T. Histamine responsiveness of isolated gastric glands. Am F Physiol 1980; 238: G312-20.

40 Negulescu PA, Machen TA. Intracellular Ca regulation during secretagogue stimulation of the parietal cell. Am F Physio 1988; 254: $\mathrm{C} 130-40$

41 Soll A. Potentiating actions of gastric stimulants on $\left[{ }^{14} \mathrm{C}\right]$ aminopyrine accumulation by isolated canine parietal cells. Gastroenterology 1982; 83: 216-23. 